\title{
Meeting the British
}

The blurb on the back cover of Meeting the British informs the reader that the volume includes 'an account of the first recorded case of germ warfare.' The statement refers to how the British finally crushed Pontiac's rebellion and tried to wipe out the Ottawa Indians by injecting smallpox into the population during the French-English-Amerindian wars in the unsettled borderlands of Canada and America in the 1760 s. Such a cynical design of genocide constitutes a terrifying part of Meeting the British and language plays no innocent role. Adorno's vision of a radically darkened art was prompted to a large extent by the horrors and holocaust of World War Two. The conspiracy of genocide of Amerindians in Muldoon's fifth volume of poetry runs in alignment with Adorno's insights. Ethnic eradication and cultural annihilation belong to the monstrous side of humanity. Muldoon's account of the murderous plan also gives the lie to ideas of language as translucent, neutral, innocent, and representational. 'Meeting the British' lays bare the prior investments, power dynamics, dissembling, and Machiavellian potential of apparently objective communication.

Encounters with the British are manifold in the volume, and not all dark, and the same spectrum of malignancy is reflected in the combined felicities and dysfunctions of language. The language of Meeting the British explores syntactic solutions, and the contextual relationality for which language is a kind of expressive interface or communicative medium. Muldoon's first three volumes thrive on a language of auto-critical in-formations, subjective correlatives and bi-located socio-political introspection. Quoof displays generative alphabetics replete with the artifice and autonomous life of letters and words, and a transfiguration of narrative and form that allows for a collage of temporality and textuality. This volume brings into focus the larger circles of language within which his innovations have their being. A slide in significance towards larger units of syntax and meaning does not signal a rupture with his former array of startling linguistics; far from it, they remain an integral part of his poetic palette in this volume too, and in those to come. Meeting the British can be viewed as a very ambiguous title that announces confrontation and conciliation where previous titles suggest alterations, liminalities, departures and a full gamut of enigmatic modulations. Interrelations between the British and the Irish, as between the British and so many other nations of the world, America included, have shaped the historical development, social engineering, aesthetic 
preferences and cognitive contours of both islands for centuries. That this meeting is not only linguistic is an obvious fact that the volume acknowledges, but these poems certainly accentuate the interactions of language across cultures. In Ireland and Northern Ireland in 1987, the title entered a discursive field and a very real situation of historical conflict, political controversy, divided societies and abhorrent violence of such magnitude and ferocity that the sectarian divisions appeared insuperable at the time. ${ }^{1}$ In his characteristic manner, Muldoon does not endorse the rhetoric of nationality, whether English or Irish, or that of communal bias or simplistic separatism, as one strand of the title reveals. British, as opposed to English, not only designates populations with whom the Irish might have more in common than with the English - the Scots and the Welsh and all the Americans of British extraction, the term also denotes the Gaelic element of the ancient Britons, the pre-Roman European invaders into both Great Britain and Ireland. Meeting the British, then, signifies inherited multicultural traces that are mutable, constituting a nexus of self and other that cannot be reduced to unitary ideas of origin, history, identity and representation. In Ireland and Northern Ireland, the title struck a raw nerve in the commotion caused by the Anglo-Irish Agreement that was signed on 15 November 1985 at Hillsborough Castle by the British Prime Minister Margaret Thatcher and the Taoiseach Garret FitzGerald. Negotiation, as the title implies, is one of the dominant metaphors in the volume and it comes as no surprise that the many meetings with the British occur on a large geo-historical scale. Nor is it surprising that the aesthetic, cultural, poetic and linguistic dimensions of the many accounts of meeting the British must overcome the dangers of militant and political confrontation, and it is to be expected that the many meetings and negotiations in the volume extend to the realm of death. The volume is dedicated to Patrick Muldoon, Paul Muldoon's father, and it includes elegies for dead relatives and friends. Death and destruction also extend to culture and language. Still, in its language contact and crossings of cultures, the volume demonstrates the complexity of a language that can never be aligned absolutely with ideas of intentionality, communication and consequence - a language that articulates its themes of encounters and negotiations. Language in Meeting the British continuously alters itself and the realities with which it negotiates.

1 'I begin with a question to which I have no answer. Why do so many people hate the British? I say "British," but what they actually hate is England and the English.' Uttered in The Belfast Telegraph as late as 2010, these words of Kevin Myers reflect some of the mood the title confronts. 
'Ontario,' the first quizzical prose poem, designates the region in which the germ warfare of the 'Meeting the British' takes place, and introduces this collection with what is evidently a premeditated disorientation of whatever type of language, poetic form and location a poetry volume entitled Meeting the British would tend to elicit or might be expected to elicit. 'Ontario' dispels intriguingly most of the title's initial connotations, just as 'The Mixed Marriage' defied customary expectations in Mules. Ontario designates a river, a lake, towns and cities on the American continent in addition to the most obvious designation, the Canadian province that was once the homeland of the Algonquian and Iroquoian indigenous people. Yet the first verse cites Pennsylvania. Consequently, any potential meeting with the British is deflected away from Ireland, Northern Ireland or England to an uncertain number of unspecified places on a continent that is now multicultural, where the British once suppressed the native population while, at the same time, the British pioneers liberated themselves from England. Parallels with potentially coercive elements in liberation movements back home are clear. In the manner the persona in 'Ontario' possibly approaches the evil from which he appears to escape - he could be a courier and his brother's petrochemical knowhow could be part of the armed struggle in Northern Ireland - and attempts to reshape his life with artistic procedures as language fails to account for his experience, this initial piece sets down the volume's themes, styles and concerns. Who is or are British in the poem? The persona? His brother? The girl? None of them or all of them? How do we know? Does it matter? What does it mean to be British? For all the relevance these questions might have had on the feuding interfaces of certain districts in Belfast at the time of the volume's publication, the introductory poem is bent on drawing readers' attention away from the obvious claustrophobic and conflictual line of thought the title suggests in Northern Ireland.

In 'Ontario', Muldoon sets up humorous, auto-critical points of departure for his own artistic methods in a volume that will reach its apex in the centre of New York in the final poem, '7, Middagh Street.' Engagement with IrishBritish relations from a distance, and the structuring of a volume around an initial self-questioning stylometric disclaimer and a final intriguing climax, are well-established trademarks in Muldoon's poetry by now. The initial and the final poem reveal how Meeting the British extends - spatially and temporally perspectives on Northern Ireland previously found in Muldoon's poetry. Festive and meta-aesthetic, these two poems also provide a relatively peaceful and highly cultured ambience for the presentation of brutality and violence in many of the other poems. Such preoccupations - origin, identity, war and peace - are also framed and formed by the negotiations of, in and with language in the poems. 
'Are you for real?' (1), a girl searching for her lost contact-lens asks her philosophical-minded aid-of-the minute in the Park Plaza disco in 'Ontario,' in a tone and with a comic lack of vision that recall the hallucinogenic inducement, nocturnal urbanity and dubious sexual encounters in previous volumes. With humour and irony the quip also pricks the membrane of the real and the imaginary, and questions the quirks and perks of Muldoon's quizzical mind, and his way with language. A multirelational question in a personal conversation in an unexpected location rendered in what is conventionally regarded as an unpoetic genre, prose, initiates the heuristic tone of linguistic self-scrutiny and self-reflexive artistry by which the diversity of cultural encounters in the collection are framed. The strobe-light tête-à-tête counterpoints a previous moment of meditative solitude that considers representation and semiotic divisibility:

The

constellations of the northern hemisphere were picked out in luminous paint on the ceiling. I lay under a comforting, phosphorescent Plough, thinking about where the Plough stopped being the plough and became the Big Dipper. (1)

In a slanted Romantic frame and with a plethora of star metaphors, which include Muldoon's own, particularly the ones in Mules, this sublunary nocturne does not provide solace or instantiate existential meditation; rather, it provokes a linguistic conundrum. What is at issue is how language refers to natural phenomena, and how the choice of words transforms our conception of them. Musings on the functions of language also preside over the conversation between the two potential dance partners: ' - Did you know that Spinoza was a lens-grinder?' '- A lens, I went on, is really a lentil. A pulse. Her back was an imponderable, green furrow in the ultraviolet strobe' (1-2). The persona's erudite semi-etymological knowledge appears ridiculous and incomprehensible to the girl in this serio-comic exchange and the quasi-etymological tracing seems to give inadequate grounds for the conflation of organic seeds and technological equipment, and offers no help in metropolitan parlance. The leap from Spinoza's lens to the pulse of adolescent excitement, throbbing rhythm and flashing strobe lights indicates the ability on Muldoon's part to shake ordinary logic and reason with a creative wave of the wand, using the contingency and play that the dance of language offers. In exchanging the abstract for the concrete, the girl's impatient riposte brings him down to earth from his lofty philosophising: ' - Did you know that Yonge's Street's the longest street in the 
world?' ' - Well, it starts a thousand miles to the north, and it ends right here' (2). Direction is hardly accidental here: The road leads from the North. The remark ends the conversation and the prose piece. As the conversation is a recollection stemming from the last time he visited his brother, the ending is subsumed within his nocturnal reminiscing, a 'rerun of my own dream-visions' (1), visions on the verge of violence that are clearly also a rerun of many previous poems. As a cliché for the mental processes at the moment of dying, the filmic rerun also intimates death. The insomniac's anamnesis takes the shape of cinematic presentation more than psychological analysis, and this technique of projection and its associated vocabulary - 'rerun,' 'flashed up, 'close-up,' 'slomo,' 'freeze-frame' (1) - assumes a mode of artificial transformation and linguistic fluidity by which many of the biographical and historical aspects of the volume are articulated. 'Ontario' negotiates the expectations of how the encounters with the British will unfold in the volume by negotiating its own language and syntax.

If the introductory poem militates against any obvious ideas of encounters between the British and any other nation, the volume's central cluster of poems, 'Meeting the British,' 'Crossing the Line' and 'Bechbretha,' enable the titular theme to be developed through accumulative alternatives. They all enact cultural confrontations which play themselves out through linguistic negotiations. Like the majority of the poems in the volume, 'Meeting the British' is historically grounded in a specific time and place. Yet its language proposes and disposes. As the title designates both the volume and a singular poem within it, it thus signifies simultaneously both a totality and an instance of that totality. Because the totality also comprehends many other poems that differ considerably from the title poem, this specific poem reflects and refracts the totality at the same time. Meeting the British and 'Meeting the British' unsettle distinct delineations of origins, centres and language. Thus, the play on titles and their conditional status in governing some of the volume's meaning, could be seen to reflect the geographical status of Northern Ireland as a separate state within and without the islands of Ireland and England. Destabilisations of semantic stability also inhere in the poem. Nine half-rhymed and assonantal couplets are set on the American continent more than 250 years ago and they cover a meeting of several populations with the English. They recount from the viewpoint of the Ottawa Indians how the British finally crushed Pontiac's rebellion in the 1760 s by employing what the blurb calls 'the first recorded case of germ warfare.' It is a history of trade, war and shifting sides among the many Indian people under Pontiac's command at a time when France and England were conducting a colonial race for the Indians' land. As the Ottawa Indians lived in Michigan and Southern Ontario, the poem visits one of the other possible sites of the opening prose piece, but the encounter with the British 
this time, more than two centuries earlier, highlights colonial cynicism, culturecide and genocide:

We met the British in the dead of winter.

The sky was lavender

and the snow lavender-blue.

I could hear, far below,

the sound of two streams coming together

(both were frozen over)

and, no less strange,

myself calling out in French

across that forest-

clearing. Neither General Jeffrey Amherst

nor Colonel Henry Bouquet

could stomach our willow-tobacco.

As for the unusual

scent when the Colonel shook out his hand-

kerchief: C'est la lavande,

une fleur mauve comme le ciel.

They gave us six fishhooks

and two blankets embroidered with smallpox. (16)

The cynical design of genocide in this poem is terrifying and language plays no innocent part. Just as Romantic patterns of nature imagery and of the unknown are rendered menacing by affectation and xenophobia in these verses, these lines also cry foul with naïve understandings of language. Indications of cultural unification by the confluence of the two streams are shattered by linguistic and ritual alienation as 'bouquet' designates not flowers but a Swiss officer in the English army, the Amerindian negotiator becomes estranged to himself by adopting French as a spurious lingua franca, and the peace pipe becomes a token of aggravation and contention. Deferral of meaning in thand/ kerchief' displaces any cordial handshake with a solipsistic gesture. This spectacular enjambment mimics corporeal dismemberment and interjects a 
sardonic irony that reinforces the poem's callous mood and sense of division. The poem testifies to the role of language in the massacre and possible extermination of Indian populations for the sake of colonial conquest: 'The only good Indian is a dead Indian.' Imperialist suppression by the English of the natives on two different continents is implied. In this respect, the particular meeting with the British relates to the discourses of history, politics and language in Ireland and Northern Ireland too. The poem provides an analogue to standard nationalist accounts of Irish history, and to the situation in Northern Ireland, as endless rapacious exploitation, shrewd systematic suppression and unscrupulous eradication of Irish language, culture and population by the merciless and inhuman English. On the other hand, the Amerinidian setting of the poem constitutes a critique of any political rhetoric delimited by its own time and location, rhetoric which might risk self-aggrandisement in its unchecked accounts of victimisation. This continues Muldoon's method of presenting the Irish Troubles through the tragic fates of native Amerindians that he first made use of in 'The Year of the Sloes, for Ishi' ( $N W$, 44-47), employed again in more oblique terms in 'The More a Man Has the More a Man Wants' $(Q, 40-64)$, and further develop in the debacle of Romanticism and Western metaphysics in the next volume, Madoc. ${ }^{2}$ Muldoon's Amerindian analogues to the immediate realities of fraught Anglo-Irish relations during the Troubles, and to the longer view of relationships between Ireland and Britain, remain active and acute.

Interestingly, in The Haw Lantern Heaney also produced a poem that attends to the negotiations of the many frontiers of land and language in the same year, 1987. His search for solutions in 'Terminus' retains a hope of uncontested ground in Northern Ireland where neutral mediation is possible:

Two buckets were easier carried than one.

I grew up in between

$[\ldots]$

Baronies, parishes met where I was born.

When I stood on the central stepping stone

I was the last earl on horseback in midstream

Still parleying, in earshot of his peers. ${ }^{3}$

2 For Muldoon's critical engagement with popularisations of Indian history and culture, see 'Western Ways. Review of Dances with Wolves by Kevin Costner,' 21; 'Big Hair. Review of The Last of the Mohicans,' 17; 'Barbie, but No Bimbo. Review of Pocahontas by Disney.'

3 Seamus Heaney, The Haw Lantern (London: Faber and Faber, 1987), 5 . 
Muldoon's poem tends to problematise such optimistic ideas of mediation through bilingualism or lingua franca to bridge these types of watershed divisions. First of all, in 'Meeting the British,' the parley is played out in the paradoxes of the supplementary double. Whatever language the go-between in the middle of the two sides chooses, he would always be implicated in the complexities of representation and supplementation. The go-between in Muldoon's poem takes the general's place but can never be his equal. This process of substitution parallels the problems of linguistic representation and supplementarity in general. Illusions of objectivity and universality are always predicated upon the logic of power and the discourses of the powerful. The socio-historical context of most languages is concentric: language tends to gravitate towards the centres of powers (those of religion, patriarchy, urban agglomerations and capital cities, empire) whenever used, however much this might be an imposed set of terms upon its very character. It becomes impossible to resort to the concept of a freight-less language, a neutral and weightless language that keeps the balance between invested powers. Any promotion of any individual or any language to the status of objectivity and neutrality is illusory because these notions are always already re-inscribed in specific national, cultural and linguistic definitions of the term. An uncontested subscription to assumed commonalities of language would automatically fall in favour of the powerful. Under such conditions, a negotiator's ignorance of his own double position and the status of the adopted language of negotiation could easily be reduced to a useful instrument for the powerful. Even if the negotiations were not a cynical sham predetermined by malevolent imperialist politics - as they so evidently are in this poem - any sublation of language from its government would already have tilted the scales. In this case, of course, French is not a neutral medium of communication - it is a result of and an instrument of colonial politics. Consequently, the native go-between is not an innocent negotiator, nor an unknowing betrayer, but already a linguistic hostage of the invaders as the parley is already structured by the (linguistic) powers of a European parliament. The supposedly neutral negotiations carried out in an objective language are actually governed by the culture of one of the interested parties. Secondly, triangular relations in Muldoon's poem problematise the issues of negotiation beyond the simplicities of two-party talks, and introduce the problematic position of the third party: the other other. Several nations, cultures and languages are involved in the negotiations in this poem: a representative of several indigenous American peoples negotiate in French with the English over their homeland, which is a battlefield for the imperial politics of France and England. The presentation in the poem of this trilateral powerstruggle by carefully paired couplets anticipates on a formal level the exclusion of any third party: the poetic form reveals a contract of exclusion of any third 
entity. At best, the Indian peoples are represented in the sole language of one of the colonial powers, but the lack of any native vocabulary in the poem indicates the complete silencing of the Indians. In an Irish and Northern Irish context, these underlying binary strictures hint at all the minority interests - those of immigrant minorities, marginalised social groups, gender disparities and sexual minorities, etc. - that are excluded in binary discourses. The implications of this language lesson range wide: in a larger perspective of philosophy, the poem illustrates forcefully the exclusivist strictures of Hegelian dynamics. 'Meeting the British' also contains other sinister contextual implications. Its strong sense of perfidy and treason prefigure the succeeding poems, 'Crossing the Line,' in which the negotiations of 'two rival commanders' are encased by numerous discourses, and the subsequent 'Bechbretha.'

'Crossing the Line' appears as the volume's prismatic poem. In its obvious reflexivity and its subject matter and form, this multifractured sonnet reflects the different concerns of the volume and reinforces Muldoon's central concerns with language. The poem enmeshes in its five phrases the prose, technostrobic ambience and dialectics of the opening poem 'Ontario,' and anticipates the meta-aesthetic disputation and the splitting, splicing and staging of sonnets in the last long text, ' 7 , Middagh Street.' It appears as the centre of three poems preoccupied with negotiation, a theme that stretches from the personal encounter in the first prose poem 'Ontario' to the many elegies for his late father, and to the balancing of aesthetic perspectives in the final series of ventriloquised monologues in ' 7 , Middagh Street.' In fact, as number thirteen of twenty-four poems, the poem also occupies numerologically the central place on page seventeen, the same page number as 'Quoof' in the previous collection. In its egregiously disjunctive syntax, calculated incoherence and uncompromising opacity, many of the lines, and their form, not only enact the problematic procedures of negotiations, but also those of language itself. The poem has received little critical attention.

A windswept gallery. With its telephones

down and the jiggery-pokery

of Quantel

dissolving in the monitors.

\section{$\S \S \S$}

Two rival commanders

are dining by candle-

light on medallions of young peccary. 
Like synchronised dolphins, their flunkeys hand each a napkin torn from the script of a seven-part series based on the Mabinogion.

\section{$\S \S \S$}

Where Pryderi's gifts of hounds and horses turn out to have been fungus. (17)

'Crossing the Line,' as the fragmented verses above make clear, is an evident renovation of a cliché. Muldoon is not averse to using clichés and popular idioms, as can be seen from his wide-ranging colloquial register, his involvement with Western and detective and pulp fiction genres, and, not least, his longstanding and enthusiastic engagement with popular music. 'Clichés are clichés for very good reasons. There's a hell of a lot in them,' he argues convincingly. ${ }^{4}$ Readers of Muldoon's poem will recognise in the clichéd title 'Crossing the Line' a medley of connotations including: communal bifurcation, military frontiers, naval navigation, national boundaries, technological mischance, moral righteousness and perfidious betrayal that pertain to the rival commanders' situation, but the first lines to be crossed in this poem are those of language and literature. A truncated, verbless, three-word first sentence violates syntactic completion and divides the initial line, as if to cut short communication from the very start. This first indefinite and modified singular noun, 'a windswept gallery,' is of uncertain grammar: is it a subject or an object, or does the unit serve a complementary, adjectival or adverbial function? Indeterminacy is suggested in this syntactic structure which instills a sense of stasis, reticence and partition relevant to the theme of negotiation. Solid stanzaic severance and obvious signs of separation in the first Faber edition (in this book replaced by three asterisks) augment the delineation of these anomalous characteristics. These self-contained but defective syntactic segments capture the communicative deficiencies of the two interlocutors, and the incoherence, discontinuity and displacements of serialised negotiations in several venues over long stretches of time. The signs of separation between the stanzas draw attemtion to what is written between the lines, and hint at symbolic codes and paragraphs of law and contract. Additionally, the text divides into further segments with decorative spacing emblems simulating the style a menu appropriate to a gastronomic agenda of food and wine, cutting deals and

4 Donaghy, 'A Conversation with Paul Muldoon,' 83. 
carving filets. This gastronomic affectation in public politics serves as a reminder of how trivial social etiquette can impinge on important talks. Similarly, these emblems of division, together with the separation of the second tercet from the first de-metricised quatrain, serve to disrupt temporal relationships to suggest difference and distance between the two commanders themselves, and between them and the windswept gallery. It is not unlikely that these negotiators are two TV-combatants who appear at a remove from themselves, dining by candlelight somewhere else while being spectators to their own television performance: negotiations take place in different venues and on different levels. The bi-focality here indicates the difference between public rhetoric and individual conversation. But there is a sinister application too: the two negotiators share a secret agenda and the TV-show was just part of the habitual smoke and mirrors of political theatre. Syntactically, the poem ends as it started, with clusters of subordinate clauses which emphasise an atmosphere of ever-continuing lack of accomplishment, a syntactic solution which might also indicate the rank of the two negotiators. In a syntagmatic sense, this poem is not only crossing its own lines, but quite simply jumping them. A dissociative syntax of gaps, lacunae and ellipses strains the structure of the poem and enacts technically the points at stake in the poem itself. This is a stratagem of syntactic significance that is extended in other poems, such as the contracombinatory constellations in 'The Plot' $(H, 15)$, the ergative syntax in 'The Turn' (MSG, 69) and the subordinate conjunctions in 'As' (MSG, 33).

Recondite terminology and aural connections corroborate the atmosphere of power-broking. 'Mabinogion' and 'Quantel:' 'Quaat?' one might ask. Abstruse words cross the lines of the poetic and the technological. With obvious echoes of the many enigmatic encounters in Quoof, 'Quantel' names a pioneering British technology company and also references Quantized Television, thus alluding to the process of converting a television picture into a digital signal. This brand name exudes public performance and secret surveillance. The technotextualities that form 'The Radio Horse' $(N W, 21)$ also interfere. The ambience of high-tech media production contains a metaphysical and supernatural dimension in the allusions to the myths and magic of a Welsh epic: Mabinogion. Furthermore, the connection of 'Where Pryderi's gifts of hounds and horses / turn out to have been fungus' to the rest of the sonnet is abrupt and seemingly illogical. The disrupted syntax and sign-divided stanzas create questions and confusion relevant to the many layers of negotiation. However, in addition to opening Muldoon's ever-expanding catalogue of canine, equestrian and mycological imagery, this magical transformation charges the poem with an aura of delusion and deception, and enables it to end with a puzzling and inconclusive departure, just as undecided as the final sonnet cycle of the book. Mabinogion, rich in phono-visual estrangement, diverts reference from the securities 
of classical, Irish and English mythology to the national epic of the Welsh - old Britons geographically placed between the English and the Irish. Significantly, these mythic tales of the eleventh century often centre on the warfare between Britain and Ireland. In Mabinogion, Pryderi is a Welsh king who is duped by the magician Gwydion into swapping his herd of swine with illusory horses and hounds. Gwydion's treacherous trick results in Pryderi's raising an army and marching north towards his enemy's lands where the two men meet in single combat. By magic as well as strength, Gwydion defeats and kills Pryderi. These allusions to the Welsh legend load the poem with possibilities of betrayal and war: the commanders can be deluded by their own idealism or succumb to corruption, they can be betrayed by each other, or the people they represent. Pryderi, as king of the underworld, operates on an epic scale and this backdrop provides Muldoon's poem with an infernal dimension that opens up questions of divine will and human fate. That the napkins are torn from the Mabigonion is a surrealist jolt that corresponds with the Dalínian streak in a volume in which the Spanish painter is given one of the final monologues. The dislodging of papers from the Welsh epic for menial purposes reveals the commanders' philistine and pragmatic attitude, just as the obvious connotations of worthless paper and torn documents signify that a potential treaty will be valuelessness. The act of destruction could also be read as an implicit comment upon the poem's own deconstructive procedures. In like manner, the misconception of fungus for hounds and horses can be read as a ludic illustration of the arbitrary relations between the signifier and the signified. This collapse of any logical referentiality endows the poem's linguistic multivalence with ominous communicative impossibility. Instead of concluding the sonnet, the multitextual allusions of the final unrhymed distich open up a world of textual play. Ultimately though, this relativistic poem does not necessarily assert the impossibility of communication and agreement; rather, it heightens the attention to language and its contexts in all interactions. Set alongside the alignments of 'Meeting the British' and Northern Ireland, 'Crossing the Line' seethes with dynamics of decline.

A sense of extenuation and equivocation characterises the rhyme scheme in 'Crossing the Line.' The unusual circular harmonics of the first and final line add a cracked varnish of self-containment to the poem as a whole. Because 'telephones' / 'fungus' is an off-rhyme that is delayed over fourteen lines, it is on the brink of short-circuiting the circular entity it attempts to establish. This distant rhyming relationship precariously encloses the sonnet within a defined space within which the many assonantal simulations are orchestrated. Muldonic internal rhyming in the poem is subtle, oblique and multivalent. It might stem from a type of Gaelic assonantal prosody that is hardly ever acknowledged in Anglophone aesthetics. In the court of English criticism, they are deemed incomplete, failed, feminine or half-rhymes at best, whereas they 
actually demonstrate novelty and strength: 'gallery / jiggery-pokery / peccary', 'Quantel / candle,' 'monitors / medallions / Mabinogion,' 'dolphins / napkin,' 'telephones / series / horses / fungus.' Tellingly, the otherwise sensitive Mick Imlah criticises this poem, as well as 'The Earthquake' and 'The Toe-Tag', for lack of rhyme. ${ }^{5} \mathrm{He}$ is right of course; Muldoon's powerful auralities defy conventional terms. His proclivity for, at times, almost indiscernible phonetic assimilation demands extra-auditory attention from the reader / listener and resists the idea of a fixed rhyme pattern, as the semi-imperceptible para-chiming patterns engender a plenitude of interchangeable shifting sounds. This instability and diminution of sound illustrate the entangled nature of any potential treaty: the astute perception required by the negotiators, and the minutiae that amount to change.

'Crossing the Line' is a specimen of the Muldonic sound spectrum. Muldoon, who 'relishes crazy rhymes' and 'finds nothing new in the assonantal and slanted rhymes of Yeats,' displays a mixture of poetic over-indulgence and artistic discipline in his syncopated sound syllabics and expansive half-rhymes, para-rhymes and para-chiming. ${ }^{6}$ Lynn Keller admires his 'wonderful invention' of rhyme and this typical Muldonic feature is found in abundance in this volume: 'Qu'Appelle / quibble' (9), 'lost a paw / Lisbellaw' and 'still-molten lava / moth-eaten Balaclava' (12), 'Guelph / grave' (14), 'unspoken / not boke in' (26), 'to the Master / alabaster' (35) - some of which are divided by numerous lines. ${ }^{7}$ Audio-visual stunts reach unprecedented intricacy in the alphabetic $\mathrm{r}-\mathrm{g}-\mathrm{n}$ combinations - 'arguing,' 'erogenous,' 'arrogance,' 'oregano,' 'orgone,' 'organs' 'Argina,' 'Aragon,' 'Eriugena' in the italicised section of 'Sushi' (34-35), but also crack, speck and swerve throughout the volume: 'organza' and 'orangery' (30), 'Oregon' (39), 'Armagnac' (40), 'orange' (53) and 'morning' (6o). Mick Imlah finds it 'a surprising fact that the most exciting feature of perhaps the most eagerly awaited poetry book of 1987 should be its rhyme - given the word's usual connotations of traditionalism, decorativeness, jingle, levity, consolation.' 8 Despite his perceptive eye and ear for many, if not all, of Muldoon's innovative and assonantal rhyme schemes, Imlah fails to apprehend their function in 'Crossing the Line' and some companion poems, complaining that they take 'Muldoon's associative method too far,' and that instead of connecting these poems, 'they're just baffling. ${ }^{9}$ Certainly, 'Crossing the Line' is a

5 Mick Imlah, 'Abandened Origins,' Times Literary Supplement, 4 September 1987, 946.

6 Donaghy, 'A Conversation with Paul Muldoon,' 80.

7 Keller, 'Interview with Paul Muldoon,' 18.

8 Imlah, 'Abandened Origins,' 46.

9 Ibid. 
baffling poem that engenders multiple associations, but it does offer authentic rhyme and chime and deploys such auralities for specific purposes. Oblique audio-visual connections in 'Crossing the Line' and Meeting the British require the reader's utmost concentration and draw renewed attention to poetic sound orchestrations. These attenuated rhymes and chimes paradoxically provoke new evaluations of established accentual and aural definitions. In an aesthetic climate inclined to disfavour rhyme in poetry, Muldoon relocates the modernist soundscape of Eliot's auditory imagination and Joyce's ineluctable modality of the audible by way of sonic innovations and sonnets: ingenious novelties not original newness. Muldoon replaces the rhapsodic rhythms and rhymes of free verse with an almost subliminal distribution of para-chimes in imploding sonnets. New and peculiar distributions of subtle sounds and homophonic concurrences that destabilise conventional patterns demand sharpened attentiveness on the part of the reader, and suggest non-traditional connections in the wider context of crossing the lines and meeting the British - in Ireland, Northern Ireland, America, England and other places.

The crossing of lines is also literary. 'Crossing the Line' is one of the sonnets most of the founders and practitioners of the form would not recognise, as are so many other variants of this traditional form in the volume. Has a sonnet ever been short-stopped in the first line this early ever before? Or the stanzas been more short-circuited, the syntax more solipsistic, or the final couplet more cryptic? The minimalist italicette in Quoof (62) - 'Just throw him a cake of Sunlight soap, let him wash himself ashore' - has taken another turn and this one also constitutes a central text in Muldoon's preoccupation with the sonnet form. Approximately two thirds of Muldoon's poems from 'Kate Whiskey' in New Weather to 'LOS DISSIDENTS' in One Thousand Things Worth Knowing are sonnets, allowing for his many transmutations of a genre that is already predicated upon flexibility. In its long development and range of creative transmutations, the sonnet always shines from Petrarch's citadel, bolsters the arch of Renaissance poetics, grows in the greenhouse of pantheistic Romanticism, or it operates on the multiple frontiers of the twentieth century..$^{10}$ Still, from an Irish perspective, the sonnet is largely an English tradition, and for the longest time a very controversial tradition. ${ }^{11}$ The celebration of amorous verse at the Elizabethan court coincided with the implementation of plantation policies in Ireland. The relations between poetic practice and coercive politics

\footnotetext{
$10 \quad$ Michael Spiller, The Development of the Sonnet (London: Routledge, 1992).

11 For a constructive reading of the sociopolitical power of literature in Ireland, see David Cairns and Shaun Richards, in particular the first chapter, 'What ish my Nation' in Writing Ireland (Manchester: Manchester University Press, 1988), 1-22.
} 
are embodied in the literature and the administration of colonial coercion by such Renaissance authors as Edmund Spenser and John Davies. ${ }^{12}$ Thomas MacDonagh and Daniel Corkery have pointed out in their classics on the literary Irish tradition, Literature in Ireland (1916) and Hidden Ireland (1924), that Irish verse centres much more on the bardic heritage and on the traditions of ballads, keenings, aislings and dinnseanchas, than on any imported English or continental poetic aesthetics. Few, if any, contemporary poets have engaged with the sonnet tradition to such an extent or in like manner. ${ }^{13}$ In this respect, Muldoon's vindication of the sonnet constitutes a cross-cultural renewal and celebration of a flexible established form. His sustained engagement with the sonnet suggests a number of hermeneutic possibilities. First of all, as has already been suggested, the sonnet offers a pressure chamber for his experiments with language - as much as it is part of that experimentation itself. Secondly, Muldoon's interaction with the form surpasses innovative refinement and constitutes a formal assault upon the underlying structures that inform the genre, in order to reveal and revive it more than to remove and destroy it. Thirdly, Muldoon commits raids upon a literary form that has traditionally been associated with the English - a very suitable approach in a volume called Meeting the British. Finally, Muldoon's scrutinizing of the form allows for political interpretations on the level of form and representation - suggesting how a traditionally flexible form perpetually retains an imbalance of two disproportionate entities, but not in his own poetry, which the four-part 'Crossing the Lines' and so many of his deconstructed sonnets show so succinctly.

'Crossing the Line' and Meeting the British were written against the backdrop of the Anglo-Irish Agreement. A politicised reading of Muldoon's sonnet is fully possible. To the extent that the conventional sonnet consists of two

12 Spenser advances his argument for the systematic colonisation of Ireland in A View of the Present State of Ireland (1596) and Sir John Davies expounds the same policies in $A$ Discovery of the True Causes Why Ireland Was Never Entirely Subdued (1612) See Seamus Deane, ed. The Field Day Anthology, 3 vols. (Derry: Field Day Publications, 1991), 175-202.

13 To assign a special place to Muldoon in the renewal of the sonnet tradition in Ireland is not meant to ignore his Irish-Anglican predecessors. Yeats's 'Leda and the Swan' appears as the paradigmatic example of the genre, but the lesser known Thomas Caulfield Irwin's Sonnets on the Poetry and Problems of Life (1881) suggests another point of departure around the turn of the 2oth century. Patrick Kavanagh's Canal Bank sonnets in the 1950s provide other stepping stones, as do Brendan Kennelly, Cromwell (Dublin: Beaver Row Press, 1983). Heaney's 'Glanmore Sonnets' (1979), 'Clearances' (1987) and 'Glanmore Revisited' (1991) are other examples. The power and flexibility of the sonnet form is perhaps best illustrated in Romeo and Juliet, Shakespeare's sonnet for the stage, in which the English Bard explores its ideas and conventions in another medium. Buz Luhrmann's film is another example from recent times 'Romeo + Juliet,' (Twentieth Century Fox Film Cooperation, 1996). 
separate entities with cross-stanzaic prosody and distributions of sounds within a continuously evolving tradition, this dissonette, in its dissipated syntax and dissociative form, could represent on an aesthetic level a deconstruction of the structural binaries that dominate the mindset of much political thinking in Northern Ireland. In a possible Republican reading, the sonnet's anachronistic, artificial and arbitrary nature reflects the political status of Northern Ireland. Other poets' many variations on the norm appear to parallel the political manipulations that have been deployed only to keep the basic social fabric intact. Muldoon's radical questioning and breaking of the mould in these imploding sonnets point to a profound self-interrogation of the unchallenged norms that underlie the textual and social structure. In this sense, the radical novelty of Muldoon's deconstructive sonnets contains seditious implications, as they instigate reconsiderations of social syntax and political grammar as well as poetic practice.

As a prismatic poem of the collection, 'Crossing the Line' centralises and refracts many aspects of Muldoon's preoccupation with language, but most of all it takes its place between the two poems with which it occupies the central position. This central poem interacts directly with the preceding 'Meeting the British' and the succeeding 'Bechbretha.' However, it also relates to the whole volume's conceptualisations of crossing, to its syntactic solutions, formal introspection, aesthetic meditations and political contexts - it even incorporates the volume's many culinary settings. As the poem constantly negotiates its own intertextual terms, Muldoon's aesthetic performance parallels political negotiations, as they too are caught up in the imbroglios of text production, interpretation and contextual awareness. Viewed by way of another framework, this situation of uncertain negotiations also stages the Bloomian anxiety of influence. Whatever interpretational frame is applied, all the linguistic misshapenness of these verses does not detract from the poem's distinction and thematic actualities; on the contrary, the poem's quality and currency are predicated upon its renovation of cliché, its syntactic solipsism, its interrogations of the sonnet and its possible politicisation. This is symptomatic for Muldoon's poetics: he dares to think language first.

'Bechbretha,' the third instalment in this triumvirate of important poems, sets the negotiations in Northern-Ireland, a little nearer to home than 'Ontario,' the Amerinidian setting of 'Meeting the British' and the suitably - as it is squashed in the middle - decontextualised 'Crossing the Line.' This 'political eye story,' a re-run of a Muldonic narrative on a different scene, constitutes a political satire in the tradition of Swift and Joyce, and negotiates with hilarity, sincerity and surreality the powers of politicians and poets 'at a garden party in Hillsborough, County Down, / ten or more summers ago' (18). The actual location refers to the place where Thatcher and Fitzgerald negotiated the 
Anglo-Irish Agreement in 1985, while its temporal setting also puts the Sunningdale Agreement of 1974 firmly within its purview. A possible spoof on Heaney's reigning sense of the government of the tongue, and not exactly a paradigm of 'poetocracy', the poetics here, apparently, plays second fiddle to the politics. Still, its title, Irish for judge and 'the Brehon judgements / on every conceivable form of bee-dispute' (19), questions cunningly jurisdictions of all kinds. Again, the assumed authority of language is put back on trial by the title, this time as an acknowledged subterfuge. Evocations of the Brehon laws recall the old Gaelic judicial system in which poets were important adjudicators, a system which was partially eclipsed by the Norman invasion of 1169, and further weakened by the penal Statutes of Kilkenny of 1367 , and finally abolished in the reign of King James I. As bee-laws, if not by-laws, would by now be obsolete anyway, these reminders of obsolete legal codes philosophise humorously on the foundations and transience of law and order, poetics and politics, at another point in the negotiations between England and Ireland over Northern Ireland. In all its parody and play, the poem also interpellates insidiously the accepted discourse of democracy. In the poem, a histrionic Enoch Powell, that perennial dissenter of conservative and unionist politics, scoops up a threatening swarm of bees in a Union Jack. The act seems symbolic of international summits which constrain unconstitutional groups from participating in negotiations. Within the political situation of Northern Ireland at the time, the poem could be seen to address the processes of democratisation on a higher level. Constitutional politics of democracy are regularly presented as a politically neutral process that tends to infer an obligation to pursue democratic principles. These principles were questioned by political parties and extreme groups on both sides of the divide that were excluded from democratic government or political negotiations. In the political climate of the 1970 and $1980 \mathrm{~s}$ the nationalist electorate was mainly divided between constitutional politics and Republican abstentionism. The militant Republican faction opposed the assumed neutral premises of successive English governments, as the militant Loyalist faction opposed those of the Dáil, due to the claims to geographical and political jurisdiction in both constitutions. Despite the fluctuations of different governments at Westminster and the lack of any written constitution, England has always appeared to resist relinquishing its hegemony in Northern Ireland. Articles two and three of the Republic's constitution also presented strong claims to rightful jurisdiction over the territory of Northern Ireland. ${ }^{14}$

14 For the nineteenth amendment of the Constitution Act, 3 June 1998, see Roinn an Taoisigh and Department of the Taoiseach, 'Nineteenth Amendment of the Constitution Act,' (1998), http://www.taoiseach.gov.ie/DOT/eng/Historical_Information/The_Constitution/ Constitution_of_Ireland_-_Bunreacht_na_h\%C $3 \% 8$ gireann.html, accessed 17 April 2019. 
It seems significant that the conflict in Northern Ireland remained intractable as long as it was predicated upon the constitutions of both Ireland and England. The peace process was only set in motion after the franchise was expanded to extremist groups on both sides, and after deconstructive constitutional discourses evolved. Many critics might deem such a reading of 'Bechbretha' tantamount to transgressing the proprieties of poetic interpretation all together, but there can be little doubt that it belongs to the wider grammar of the trilateral poetic negotiations at the heart of this volume.

As the central poem of the volume, 'Crossing the Line' is a vehicle for an other spectrality: the cliché also connotes the traversal across the divisions of life and death, with further implications of negotiations with unknown and unmapped regions, and with loss and sorrow. Previous volumes staged several spurious elegies for Muldoon's undead father; this volume, as the initial epigraph states, is written 'in memory of Patrick Muldoon 1910-1985' (xii). Poems on the loss of his father, and of relatives and acquaintances, are corroborative of the destruction of civilisations, the ruin of cultures and the demise of language, but also serve as a reminder of how the spirits of the dead and gone haunt our present-day world. Surreality in 'The Coney,' ekphrasis in 'My Grandfather's Wake', biomorphism in 'Brock' and taxidermy in 'The Fox' all exhibit mechanisms of grief and awareness of twilight spaces occupied by the living and dead; 'The Wishbone,' as the title indicates, brings the father back to life. Language, however, casts an aleatory and apprehensive shadow over these poems, signifying annihilation and the afterlife. Indubitably, the life and death of language itself inform and deform these plaintive poems. Coney, for example, formerly the proper and ordinary name for rabbit, now recedes more into obsolescence by the day, not unlike how the memory of the dead retreats in the memory of the living. In some districts applied to a young rabbit but elsewhere more properly to an old one, coney involves both father and son in morbidity and death. Unusually for Muldoon, the term's associations of femininity are not exploited as an appropriate acknowledgement of his mother's death in 1975. Colloquial phrasing and idiolect - 'Go back to bed. / It's only yon dog-fox' (24) - mark regional and familial propinquity and feature extensively in all these dirges. Sometimes, a resuscitation of solid rhymes in Muldoon's otherwise ethereal chime schemes - 'plank / tank' and 'cap / gap' (3), 'dream / steam' (5), 'Wales / tales / slaves' (12) and 'box / fox' (24) - attempts to hold on to what is inevitably slipping away by reverting to old rituals. The fate of language is

For information on the peace process and the Easter Agreement in 1998, see Jeson Ingraham, 'The Irish Peace Process,' Conflict Archive on the Internet, http://cain.ulst .ac.uk/events/peace/talks.htm. 
resonant of human frailty in these elegies for his father, and aspects of linguistic plenitude disappear with his passing.

More elegies for friends and evocations of unknown and unknowable realms enhance this sense of evanescence. 'Christo's' drapes the famous international environmental artist and Irish nation in the shrouds of Christ, in a complex requiem to the oncoming changes of landscape, fate of political prisoners, weakened religious beliefs and diminshment of aesthetic autonomy. On a more personal note 'The Soap-Pig,' Muldoon's lament for his friend and ввС colleague Michael Heffernan, embodies in its titular emblem fragility, endurance and the cleansing powers of companionship and commemoration. 'Your soutane- / pocket like the scar / of an appendectomy' (7), the dismembered line in 'Gold,' Muldoon's elegy for Gerard Quinn, the teacher at St. Patrick's college who introduced him to the poetry of Frost, synthesises in its surgically precise stanza and cauterised clause the severance of Quinn from life - a severance so extreme in the disjecta membra of these verses that even all the suturing allusion to Robert Frost struggles to stitch them together. Terse and tacit textual snippets are infused with names from myth in centrifugal fashion: Merlin; from literature: Frost; from history: Kennedy; from film: Monro; from visual art: Soutine - all the deceased of fiction and fact that have impacted upon Muldoon's volume Meeting the British, and upon the future in which we now live. Double negations in severely amputated syntax in the two final lines signify the total depletion of life and sonnet: 'Not Soutine's / Hare on a Green Shutter. / Not Marilyn' (7). However much the elegy is contained within the dissonant chime of the first line's 'Merlin' and the final line's 'Marilyn,' its dissected syntax and its ruptures and dissociations, bewildering and exasperating as they are, embody the severance, the bereavement and the disintegration of mind in the face of death. Death and demolition in these lines also mark the end of this extremely disjected idiom in Muldoon's language from its very beginning. 'Gold,' 'The Wishbone,' 'The Earthquake,' 'The Toe-Tag' and some sections of the multistylistic end poem, ' 7 , Middagh Street,' subscribe to the poetic template of which 'Crossing the Line' is the fullest example. For all their brilliance in demonstrating death and destruction in a language that also disintegrates, dies and survives, these poems tend to lack in their language any prospects of aesthetic balance or promise of continuance by which the spirit of the deceased lives on. Later elegies and commemorations, such as 'Incantata, 'Yarrow, 'Herm,' 'Turkey Buzzards, 'Sillyhow Stride' and When the Pie Was Opened, just to mention some of the personal dirges and not other kinds, for example Wayside Shrines, manage in more affective ways to combine the survival of the spirit with the demise of the body.

Death and destruction and life-coping strategies come natural to a poet who has endured conflict and war, as does a profound ambivalence about the 
possibility of fathoming such exigencies in language. Jacqueline McCurry labels Muldoon 'Northern Ireland's mischieftain,' and captures thus his mercurial language, supple syntax and shrewd stratagems of dissociative assemblage, as much as his bi-focality on imperialism..$^{15}$ The agenda of meeting the British, even of defining and refining the sense of encounter and nation involved in the title, continues by abstraction and aberrant agglutination throughout the volume. Language informs, investigates and interrupts the convergences and divergences. 'Chinook,' for example, which in its river setting flows with ripples from 'The Waking Father,' invites no easy interpretation in terms of language, politics and aesthetics, as the semantic multiplicity of the title indicates Indian people of Oregon and the pidgin that once developed in that area, the warm winds of America, and the Boeing battle helicopter so well-known from all the wars in Vietnam, the Falklands, Iraq and Afghanistan, as well as the salmon also known as 'quinnat' that figures in the first few lines. Syntactically, the poem also moves from the security of the first three complete sentences to a welter of one-worders, clauses and phrases that tend to make it a syntactic wobble as much as 'a semantic quibble' (9), as the self-defining comment declares. In 'Prufumo,' 'a month-long news embargo on his very name' (8) summarises maternal censure and didactic reading recommendations. "The MistNet' renders in a one-sentence, syntactically convoluted text of subordination and imperative the fabric of the bird-trapping device of the title, just as much as the airy eight-line rhyme'mist-net / mustn't (10) is indicative of escape from traditional entrapment. Both designs parade Muldoon's high-flying jinks, his poaching for le mot juste and his Joycean snaring of sentence structure, as well as the problems of capturing the elusive meaning of his poetry, in a poem where the persona attempts to elude a dying mother's moralizing, and in which the lines connect with the micro-tagging of salmon and the parental guidance in the two previous poems, and with the famous Daedalian flight from the nets of family, church and nation in Joyce's A Portrait of the Artist as a Young Man. Run-on and and end-stopped lines in 'The Marriage of Strongbow and Aoife' equate relationship and union with discordance and endings. Integrations of historical and personal relations also dominate 'The Wishbone.' The silencing in this poem of the Queen's Christmas Message on TV by father and son displays quotidian opposition to English rule, a reverse act of Thatcher's silencing of Republican leaders on British television. Parataxis and divisive sign emblems also suggest family division and broken promises in this fractured sonnet, which connects with the succeeding 'Lass of Aughrim' as the fibula to the tibia. Evocations in the latter of Joyce's 'The Dead' and Roland Joffe's film

15 Jaqueline McCurry, 'A Land “Not Borrowed” but “Perloined," New Hibernia Review 1, no. 3 (1997), 49 . 
'The Mission' allude to an Irish and an English anxiety of influence, and hint at the possibility that 'the tibia / of a priest / from a long-abandoned Mission' (15) belonged to an Irish priest. Similar poetic parataxis pairs 'The Toe-Tag' and 'Gone.' 'Toe-Tag' follows morbidly and logically from the preceding elegy 'The Soap Pig' and the title of the succeeding one-sentence sonnet 'Gone' encapsulates the death in the preceding fragmented 'Toe-Tag,' and its own break-up of relationship, and its confirmation of a sale at an auction. Syntactic splits and stanzaic fissure enact their own titutlar divisions in 'The Earthquake:' of the Irish at home and abroad: 'Ireland has moved; they haven't' (23). 'At any moment now this should connect' (32), runs a quintessential line in the ekphrastic 'Paul Klee: They're Biting,' but the long-lined couplets connect only the literary and the painterly, not the estranged lovers. An extra verse extends the fifteenline one-sentence sonnet 'Something Else' beyond its expected end to retain the disappearing moment of life in the poem, and to indicate an extension of its story into the illimitable grief that follows. The language of Muldoon's poetry alters ideas of language per se, and thereby also the themes of life, death and politics with which it negotiates.

Self-reflexive syntax, forensic stanza construction, recherché lexicon and flamboyant alphabetic gamesmanship continue to underline the wide-ranging concerns of Muldoon's poetry and nowhere in this volume is this panache more prominent than in 'Sushi.' Perhaps an apologia for auto-aesthetic art all together, this delicious dish of self-indulgent delight displays a gastronomic relish for an artifice that threatens to annihilate its own importance. Yet another poem on the dissolution of relationships - perhaps the one that was initiated in 'Ontario' - and all the distractions of mind and associations of death that sometimes accompany such traumas, this immersion into the art of sushi serves up its own well-prepared language on a plate:

\author{
Is it not the height of arrogance \\ to propose that God's no more arcane \\ than the smack of oregano, \\ orgone, \\ the inner organs \\ of beasts and fowls, the mines of Arigina \\ the poems of Louis Aragon? (35)
}

For all its off-hand humour, this question - an apotheosis of the art of sushi to which fundamentalists of many kinds might answer yes, with indignation, retains a metaphysical perspective on worldly matters and the divine. Abruptly inserted, like the whole poem's sudden glimpse into Japanese culture in a 
volume of ever-expanding negotiations with varieties of Britishness, these lines are set apart by italicisation. Italicisation here marks out these lines as a distillate of language, philosophy, religion and art but, above all, a distillation of Muldoon's own writing. As a citation without source arriving from a place apart, another alterrative, this apposition recalls the border regions which all the elegies of the book have as their locale, and it sublimates the many culinary settings of the volumes and concentrates the volume's turnings of language. The italicised interjection, in its separation and completion, assumes such power and authority that it almost subverts the autonomy of the sentence to which it belongs - an effective enactment of the relations between the parts and the whole in Muldoon's poems. Such procedures of supplementarity are reinforced by the chain of rhymes and the reiteration of the letters $r-g-n$ that unite the segment, and also appear throughout the volume. Many of the words also serve these circumloculations of language. 'Aragon' highlights the surreal streak in many of the volume's poems and the string of (half-)rhymes that ends with 'Arigna', as much as it intones the sound stretching of 'arguing' in the first verse and 'Eriugena' in the final, a slanted stereophonic slur which spans fifty lines. The word 'orgone' denotes excess sexual energy and universal life force in the psychoanalytical theory of Wilhelm Reich, while at the same time incorporating the title of the previous poem 'Gone' that seems to reveal a lack of these energies. As a filet on Muldoon's linguistic platter that also introduces ' 7 , Middagh Street,' the next and final gallimaufry in the volume, 'Sushi' is served up as a delicacy of syntactic savouriness and belletristic gourmandises, with a chef's knowledge of the fishiness of the dish - fait accompli.

' 7 , Middagh Street' supplements the widening circle of encounters, negotiations and language with the British that stretches from 'Ontario' to 'Sushi,' as the final corona both reconfigures and complements the many ideas in the book up to this point. The title underscores the book's tendency to locate itself in historical place and time: 7 , Middagh Street is the actual location of the house in New York where the seven modernist stars who give their monologues in the poem - Wystan Hugh Auden, Gypsy Rose Lee, Benjamin Britten, Chester Kallman, Salvador Dalí, Carson McCullers and Louis MacNeice - congregated for Thanksgiving dinner in $1940 .{ }^{16}$ William Wilson describes aptly the poem as an 'ad hoc Mecca of late modernism' and the implicit encounters in this poem of personalities, nationalities, sexualities, art forms, poetics and politics, and the negotiations between them, are much in evidence here, as they

16 Much of the well-known circumstances of the poem can be found in: Humphrey Carpenter, W.H. Auden: A Biography (Boston: Houghton Mifflin Co., 1981); Sherill Tippins, February House (Wilmington: Mariner Books, 2005). 
are throughout the preceding poems. ${ }^{17}$ Formally and linguistically, too, the multistylistic poem is one more ingredient to the volume's overall variety. The title's number seven also addresses the poem's numerology: seven is the common denominator of the rhyme royal, the single and double sonnets and the fourteen and twenty-eight-lined clusters of couplets that dominate the poem. A snippet from Shakespeare's sonnet 109 is italicised: 'Save thou, my rose; in it thou art my all' (42). Ekphrastic tendencies, most notably in the Dalí section, of course, embrace the music of Britten, the vaudeville of the ecdysiast Rose Lee and the novelistic art of McCullers. Subtle half-rhymes and audacious rhyme pairings continue: 'pencil / Rapunzel' (38); 'oracle / rhetorical,' 'construction worker / soda fountain jerker' (39); 'Minneapolis / my nipples' (42) and 'lemon / Ashmolean' (42). Tricks of crossing the line now transmute into connecting the poems; the first line of each new poem connects with or continues unbroken from the last line of the preceding one. 'Quinquereme of Nineveh from distant Ophir' runs the first fabulous line of the poem, and the three first words, 'Quinquereme of Nineveh,' also end the poem. This design, well known from the beginning and end of Finnegans Wake, adds a circularity to the corona that befits the poem's questioning of the recurrent and somewhat insoluble problem of the revolutionary potential of poetry. It also exudes a cyclic sense of history and aesthetic organisation familiar from Yeats's Vision, and Joyce's engagement with Vico. Word choice here highlights Muldoon's predilection for the exotic and the recherché, and opens up the orientation of the book. The first and final line also form an unacknowledged citation from former English Poet Laureate John Masefield's elegy for empire, 'Cargoes,' a poem which implies an alternative organising template for the many journeys and ballasts of this volume, and which surreptitiously undermines from the very start the status of all the celebrities that have signed in at 7 , Middagh Street. ${ }^{18}$ The insidious imperialism of language is also demonstrated by the Anglicisation - or is that Gaelicisation? - of Dalís name, the only non-English-speaking member of the group, into 'O'Daly' (59).

' 7 , Middagh Street' recirculates the themes, stylistic order and language phenomena of preceding poems, but it also refines them into a larger rationale. In a theoretical perspective of poetics the poem is not only an 'ad hoc Mecca of late modernism' as Wilson suggests, its revolving of aesthetic propositions engages with poetic concerns of its own day in 1987 , and incorporates the many turns and trajectories that have ensued from late modernism. ${ }^{19}$ Muldoon's meditations upon the international problematics and apparently insoluble

\footnotetext{
17 William Wilson, 'The Grotesqueries of Paul Muldoon,' Eire-Ireland 28, no. 4 (1993), 28.

18 John Masefield, Selected Poems (New York 1923), 56.

19 Wilson, 'The Grotesqueries of Paul Muldoon,' 28.
} 
issue of the relations between poetry and politics relate to Heaney's dramatic dialogues on similar themes closer to home in 'Station Island' (1987). Typical modernist propositions are contested in Muldoon's poem: the poem's plural and mixed positions on the responsibilities, or lack of responsibilities, of poetry tend to collide Adorno's defence of aesthetic autonomy with Derrida's deployment of deconstruction and contextuality, and to reflect the Bloomian anxiety of influence to no little degree, particularly in the hilarious misprisions of Yeats. As exiles in New York, most of them from Europe, each participant accounts for his or her journey to New York and the life in the metropolis in monologues that mainly concern the role of the artist in times of war. ${ }^{20}$ Auden's Marxist repudiation of the political powers of poetry - 'For history's a twisted root / with art its small translucent fruit // and never the other way round' (39) counterpoints Yeats's and certainly MacNeice's entertainment of the possible potential of poetry: 'For poetry can make things happen - / not only can, but must -‘ (59). ${ }^{21}$ Dali's exile from Franco's Spain, and his constant surrealist clashes with his own group and his own art, add another twist: how do you transgress your own seditious surrealism without reinserting yourself into the forces of fascism, religion and capitalism that you set out to undermine in the first place? The grand questions of politics, in the traditional sense, surrounding the lives and art of Yeats, Auden, MacNeice and Dalí, are set against the less politicised lives and art of Britten, McCullers, Lee and Kallman, who serve more as counterfoils to the reverberations of thoughts on responsibility and political debates on artistic power and purpose. Nevertheless, their acts enlarge

20 For Muldoon's comments upon tiptoeing the fine line of poetics and politics in Northern Ireland, which he also deals with in poems such as 'Lunch with Pancho Villa' ( $M, 11-14)$ and 'Gathering Mushrooms' (Q, 7-9), see Kendall, Paul Muldoon, 124-125; John Redmond, 'Interview with Paul Muldoon,' Thumbscrew 1996, 17; Keller, 'Interview with Paul Muldoon,' 28-29; Kevin Smith, 'Lunch with Paul Muldoon,' Rhinoceros 4 (1991), 76; McCracken, 'A Northern Perspective: Dual Vision in the Poetry of Paul Muldoon,' 101; Longley, Poetry in the Wars, 12-13; Donaghy, 'A Conversation with Paul Muldoon,' 85; Haffenden, Viewpoints, 37.

21 For Auden's engagement with Yeats and his politics, see his elegy for and essay on Yeats in Edward Mendelson, ed. The English Auden (London: Faber and Faber, 1977), 389-393. For the debate on the political effects of Yeats's famous play Cathleen ni Houlihan, see the selfrecriminatory swagger in his own poem 'The Man and the Echo' and Stephen Gwynn's review of its production at The Abbey in 1902 in Norman A. Jeffares, ed. W.B. Yeats: The Critical Heritage (London: Routledge, 1977), 376-380. See also O'Brien, 'Politics and the Poet,' 11-12; Roy Foster, W.B. Yeats - a Life: The Apprentice Mage 1865-1914 (Oxford: Oxford University Press, 1997), 248-262. For Muldoon's many evocations of Yeats in these ghosttormented verses, see Jonathan Allison, 'Questioning Yeats: Paul Muldoon's “7, Middagh Street," in Learning the Trade: Essays on W.B. Yeats and Contemporary Poetry, ed. Deborah Fleming (Chesapeake: Locust Hill Press, 1993), 3-19. 
the scope of aesthetics and language beyond the limits of the poetic and the written and spoken word.

In these respects, the concerns of ' 7 , Middagh Street' parallel Muldoon's artistic dilemmas and anticipate his move to the USA in the year of the volume's publication, 1987. The poem can be read as a subjective correlative for his own alterratives and pluralist poetics that always oppose the monologic and univo$\mathrm{cal}$. The seven monologues propose a spectrality of ideas and language pertinent to his poetic strategies: 'I am interested in ventriloquism, in speaking through other voices. I suppose some kind of tone creeps through but I don't want to locate it.' 'I've become very interested in structures that can be fixed like mirrors at angles to each other.'22 As a poetic symposium on performance and polemics, it can be hard to detect Muldoon's position in the ventriloquist circle, just as it is difficult to distinguish the philosophy of Socrates from that of Plato's in the latter's dialogues. Critical responses testify to the success of Muldoon's spectral stratagem of relativisation. Kendall characterises the poem as 'a surreptitious elegy for Yeats,' in which 'one of its achievements is to exercise, or at least to torment, the ghost of Yeats. ${ }^{23}$ Yeats's texts haunt all the monologues and Muldoon keeps his spirit alive by acting the unappeasable host. John Drexel concludes his review by claiming that Muldoon 'is certainly not looking over his shoulder for the ghost of Yeats. Such audacity is clearly out of the Audenary. ${ }^{24}$ Clair Wills admits that 'Muldoon surely also sympathises with Auden,' but seems much more attuned to Muldoon's poem by arguing that 'the temptation in reading " 7 , Middagh Street" is to identify Muldoon's position with MacNeice's,' a claim which Muldoon's propinquity with and interest in MacNeice tends to second ${ }^{25}$ Both poets were born in Northern Ireland and worked for the ввс, both take a strong interest in the classics, employ a diversity of genres, and converge on Yeats's oeuvre. Furthermore, Muldoon has exhibited a long-lasting fascination with MacNeice's' writing. ${ }^{26}$ The length of

22 Haffenden, Viewpoints, 134-136.

23 Kendall, Paul Muldoon, 128.

24 John Drexel, “Threaders of Double-Stranded Words": News from the North of Ireland,' New England Review 12, no. 2 (1989), 172-192.

25 Wills, Reading Paul Muldoon, 132.

26 In an interview, Muldoon explains: 'I think MacNeice is very good. Some of the poems are quite extraordinary, like those in The Burning Perch for instance - there's really nothing like them. Vast tracts, of course, are sheer dull trackless desert ('Autumn Sequel' and stuff like that) - but the best of what he wrote is very good. He overdoes the parable a bit sometimes, but his best little parables are marvellous, like 'The Taxis,' which is an astonishing poem. I'd love to be able to write a poem like that, and feel very close to the spirit of 'The Taxis.' I can't really explain why because I'm no good at talking in critical or academic terms: but the tone of voice and humour and the bleakness of it, and the fluency and the 
MacNeice's monologue and the authority of its place at the poem's conclusion also weigh in on MacNeice's side. Muldoon's impersonation of MacNeice also indicates, with grim humour and inscrutability, a sense of an inescapable responsibility from the nets of past alliances, especially since this final poem reverts to the location, complexities and negotiations of and with Belfast. The poem revisits historical dates and scenes of conflict and troubles in Northern Ireland in what appears to be the final showdown of meeting the British. But some of the final lines also vindicate their own voice and their right to speak:

\author{
After drinking all night in a Sands Street shebeen \\ where a sailor played a melodeon \\ made from a merman's spine \\ I left by the back door of Muldoon's (6o)
}

That MacNeice, the ventriloquist voice here, takes the back exit from Muldoon's, is an obvious prank of Bloomian revisionary and antithetical reading, and an instance of the younger poet's overcoming of anxiety in respect of his senior, by which his poetry also transforms our understanding of his senior's achievement. The scene in the poem projects how the poetry of MacNeice develops within Muldoon's aesthetic premises to seal the affinities between the two poets. It also, of course, illuminates how Muldoon's poetry always stems from Muldoon's poetry; in this case the lines play on the mellifluousness and imagery of bones and brine in 'The Lass of Aughrim' $(Q, 15)$ and 'The Merman' $(M, 39)$. Perhaps MacNeice is the persona ventriloquising Muldoon the most vociferously, but overall this problem remains unresolved.

surreal element of it, and yet the fact that in the middle of all this great invention it never leaves the real world ... 'The Introduction' also is an extraordinary poem. But he got involved in a bit of self-parody in that book too.' Clair Wills, Nick Jenkins, and John Lancaster, 'Interview with Paul Muldoon,' Oxford Poetry, no. 1 (1986/7), 17. Muldoon also exults and elaborates on MacNeice's example in his own critical writing in Paul Muldoon et al., 'How to Peel a Poem,' Harper's Magazine, no. September (1999), 49-54; The End of the Poem, 26-27; To Ireland, I, 89-96. MacNeice is given the largest number of poems in Muldoon's Faber Book of Contemporary Irish Poetry (1986) and instead of an introduction to the anthology, Muldoon cites the famous radio debate between F.R. Higgins and MacNeice. Muldoon gave one of the keynote lectures, together with professors John Stallworthy, Jonathan Allison, Peter McDonald and Terence Brown at the Louis MacNeice Centenary Conference and Celebration at Queen's University Belfast in September 2007.

AA, 'Louis MacNeice Conference and Celebration Programme,' The Seamus Heaney Centre for Poetry, https://www.qub.ac.uk/schools/SeamusHeaneyCentreforPoetry/FileStore/ LMN/programme/. 
'It is hard not to conclude that the poetry of commitment, in some carefully limited way, has won this round' argues Paul Scott Stanfield. ${ }^{27}$ It is hard not to ask of what this commitment might consist. MacNeice, Dalí and Auden - and Yeats, by his irrevocable haunting spirit - emerge, erroneously perhaps, as the most obviously important figures of the modernist mêlée and their sense of commitment is diverse and transient, and perhaps even non-existent, depending on which criteria one applies. Although few, if any, critics have noted how the other characters reflect and refract Muldoon's poetics, they certainly do. Britten manifests much of the unexpected musicality of Muldoon's poetry and his writing of the libretti Shining Brow and Bandana; Rose Lee embodies his insatiable word-lust, intransitive language and unusual portrayal of women from 'Big Liz' in Mules to the S--- figure in 'Yarrow' and Vera of Las Vegas; McCullers represents his novelistic features and sorties into Amercian culture; and Kellman points to Muldoon's extensive collaborations in various fields of the arts. This game of ventriloquism and identification is certainly entertaining but misses much of the central point, which is not to define Muldoon's own voice, far from it. First of all, Muldoon's enigmatic variations rehearse modernist art with a difference. Secondly, the ventriloquistic variety issues an admonition against exactly such tendencies towards biographical identification: the sheer pluri-vocality and undecidability of the monologues offer countercurrents to the mainstream tendency to link up any poet with a single writer or wave; for example Muldoon with Yeats, MacNeice, Auden or Heaney, or with Martian, New Formalist, New Narrativist or New York schools, or with modernism and postmodernism for that matter, when his poetry ranges more widely and actually contributes to the establishment of the criteria by which contemporary poetry is assessed. ${ }^{28} \mathrm{~A}$ poet's commitment to creativity at the levels of

27 Paul Scott Stanfield, 'Another Side of Paul Muldoon,' North Dakota Quaterly 57, no. 1 (1988), 143 .

28 The distribution of contemporary poets to the poles of either Yeats or Joyce - as if one cannot go to both wells or drink elsewhere - finds its legacy in the fairly standard schema of authorial coupling, for example Heaney/Muldoon in Moi, 'Transtextual Conceptualizations of Northern Ireland,' 217-229; 'The Testament of Cresseid by Seamus Heaney and Medley for Morin Kuhr by Paul Muldoon,' Irish Studies Review 13, no. 4 (2005), 277-281; Elmer Kennedy-Andrews, 'Heaney and Muldoon: Omphalos and Diaspora,' in Paul Muldoon: Poetry, Prose, Drama (Gerrards Cross: Colin Smythe, 2006), 101-127; Corcoran, 'A Languorous Cutting Edge: Muldoon Versus Heaney?' 121-137. For a coupling of Muldoon with Michael Longley, see Brearton, "Ploughing by the Tail": Longley, Muldoon and Anxiety of Influence,' 1-16. Two of Edna Longley's couples are Mahon/MacNeice and Muldoon/MacNeice in Edna Longley, Poetry in the War and The Living Stream: Literature and Revisionism in Ireland. Heaney/Kavanagh is another typical dyadic couple in Northern/ Irish poetry. 
the canon, community and the individual artist varies at any one stage in his career, as do the evaluations of these groups and entities, as well as the very criteria for these evaluations. Such a fluctuating stance in and on literary aesthetics certainly opens the floodgates to a Heraclitean flux, but this is a flux pertinent to artistic licence, aesthetic reorientations and social becoming, and to the ever-evolving currents of language and seas of semiosis. Such flux, uncertainty and open-endedness also challenge societies predicated upon fixity, security and segregation.

'7, Middagh Street' constitutes a meta-aesthetic symposium. Terry Eagleton comes closest to capturing the importance of its ventriloquist variety when he terms the poem 'an ambitious meditation on the recurrent Irish theme of art and politics' in which 'the problem of how neither to overprivilege or underrate the political relevance of art remains ambiguously suspended.'29 The Brooklyn Heights septet, this 'beguiling mixture of the serious and the silly,' as Mark Ford calls it, launches itself as a postmodernist sound- and showcase, much more than a replay of the modernist question of political engagement and aesthetic autonomy. ${ }^{30}$ Its commitment to language is thus a befitting one. English functions as the lingua franca, with all its shades from self-perceived neutrality to imperialistic imperatives, to the English, American, Northern Irish and Spanish speakers at the symposium. A poem-linking sentence structure seals off the final section as a closed-circuit surveillance of its own centrality amidst canonical characters. Italicisations evoke the unappeasable spirits of past poetics and recent literary theory.

Muldoon's encounters with the British are of diverse kinds; in time, in place, in culture and thought, and in language. Surprising situations, cryptic conceits and cultural involution rewrite many of the habitual associations of the title in Ireland and Northern Ireland at the time of its publication. This is a volume which inspects the very sense of Britishness, and in which the British, however it or they are defined, meet themselves as much as they are met by the other, or the other other. Language, especially in the terms of syntax, assumes a wider significance: the volume crosses the lines of history, biography, politics and poetics. Sentence form becomes essential to the negotiations and to the complex interrogations of identity and history which the volume undertakes. Vacillations in syntax, from the prose in 'Ontario' and the looped lines in '7, Middagh Street' to the curt, cut and chopped phrases of poems such as 'Gold,' 'Crossing the Line' and 'The Toe-Tag,' do not merely suit the themes of conversation and aesthetic sodality, death, mediation and disintegration; they also

29 Terry Eagleton, 'Fishmonger's Window,' The Observer Review, 3 March 1987, 25.

30 Mark Ford, 'Out of the Blue,' The London Review of Books, 10 December 1987, 20. 
reflect the continuance and contingency of history, the significance of location and dislocation, and the importance of solidarity and serendipity in aesthetic exchange. While acting susceptibly on the longer stretches of language, the volume also points to and differentiates the shifting contexts within which language occurs: personal relations, political pressures, historical condition, social structures and aesthetic orientations. Always with an uneasy awareness of the many aesthetic and actual realities with which it interacts, Meeting the British negotiates these intimacies and interactions by way of havoc and spectrality in its language. 